\title{
Pollination Methods and Integrated Fertilizer Influenced the Pollination Rate, Fruit Development, and Quality of Cucumis melo L. under Greenhouse Conditions
}

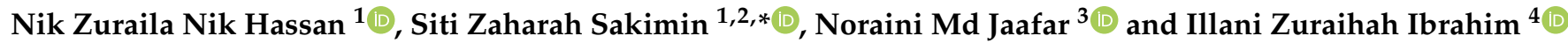 \\ 1 Department of Crop Science, Faculty of Agriculture, Universiti Putra Malaysia, \\ Serdang 43400, Selangor, Malaysia; nikzurailanikhassan@yahoo.com \\ 2 Institute of Tropical Agriculture \& Food Security (ITAFoS), Universiti Putra Malaysia, \\ Serdang 43400, Selangor, Malaysia \\ 3 Department of Land Management, Faculty of Agriculture, Universiti Putra Malaysia, \\ Serdang 43400, Selangor, Malaysia; j_noraini@upm.edu.my \\ 4 Soil Science Research Centre, Malaysian Agricultural Research and Development Institute (MARDI), \\ Persiaran MARDI-UPM, Serdang 43400, Selangor, Malaysia; illani@mardi.gov.my \\ * Correspondence: szaharah@upm.edu.my; Tel.: +60-127847290
}

check for updates

Citation: Nik Hassan, N.Z.; Sakimin, S.Z.; Jaafar, N.M.; Ibrahim, I.Z. Pollination Methods and Integrated Fertilizer Influenced the Pollination Rate, Fruit Development, and Quality of Cucumis melo L. under Greenhouse Conditions. Sustainability 2021, 13, 13300. https://doi.org/10.3390/ su132313300

Academic Editor: Imre J. Holb

Received: 31 August 2021

Accepted: 17 November 2021

Published: 1 December 2021

Publisher's Note: MDPI stays neutral with regard to jurisdictional claims in published maps and institutional affiliations.

Copyright: (c) 2021 by the authors. Licensee MDPI, Basel, Switzerland. This article is an open access article distributed under the terms and conditions of the Creative Commons Attribution (CC BY) license (https:/ / creativecommons.org/licenses/by/ $4.0 /)$.

\begin{abstract}
This study was conducted to determine the effect of pollination methods (PMs) and integrated fertilizer (IF) application on the pollination rate, yield, and fruit quality of rockmelon (Cucumis melo L. var. Reticulatus cv. Glamour). This factorial experiment was arranged in a split plot design with four replications. Two rates of IF between chemical (CF) and organic (OF) fertilizer were investigated, namely, T1 (100\% CF), which served as a control, and T2 (75\% CF + 25\% OF). The three PMs used in this study were natural (NP), bee (BP), and human (HP) pollination. Data collection included the pollination rate, yield, postharvest quality (soluble solids content, color, firmness, sugar, and organic acid), and macronutrient content in leaf tissue. The results of this study showed that there was an interaction of the pollination rate between PM and IF; however, the number of bees that survived decreased over time. The yield quality showed an interaction between PM and IF for both the fruit diameter and weight, while no interaction between PM and IF for the organic acid and sugar contents was observed. In conclusion, T2 application combined with BP reduced CF utilization, which benefits the development of a sustainable rockmelon production system.
\end{abstract}

Keywords: rockmelon; integrated fertilizer; pollination rate; yield and quality; sugar and organic acid

\section{Introduction}

Trigona thoracica (Hymenopetra: Apidae; Meliponini), known as the stingless bee, is a small insect categorized into the honey bee group. It is also called lebah kelulut and is the most popularly used for honey production in Malaysia due to its higher nutrient level compared to other honey bees [1]. Moreover, giant honey bees (Apis Dorsata) have also been reported as being an important pollinating agent of different fruit and flower species, as well as other plants in forests [2].

Pollination can naturally occur in the presence of insects in an open planting system [3]. However, human assistance is needed if grown under a closed fertigation system [4]. From a botanical perspective, rockmelon (Cucumis melo L.), belonging to the Cucurbitaceae family, is monoecious and has imperfect flowers, which means that its pollination occurs only when pollen is transferred from male flowers to female ones [5,6]. Generally, the production of rockmelon is labor-intensive when it comes to assisting pollination, especially in a closed or greenhouse system. However, Jacobson reported that using bees to pollinate monoecious plants is a labor- and time-saving alternative for fruit quality improvement [7]. In a previous work, the blueberry (Vaccinium corymbosum) was pollinated by stingless bees 
(Melipona mallifera L.) and produced significantly heavier as well as a greater number of fruit than self-pollinated blueberry plants [8].

Usually, honey bees (Apis mellifera) are easily found in natural environments such as forests, which have clean and fresh air. Apis cerena (Korea's native bee) is more suited to being kept deep in mountains, abundant in natural and fresh environments [8]. Bees are also very sensitive to any pesticide used during agriculture production [9], as shown by a reduction in bee colonies when testing pesticide pollution using bees as bioindicators [10].

Rockmelon is in high demand and is very costly to produce, especially when using chemical fertilizers $(\mathrm{CFs})$, which are not environmentally friendly. Another problem is that more workers are needed to pollinate rockmelon flowers. To find a solution to combat the unfriendly usage of CFs and the heavily laborious pollination process, our research hypothesis is that the integration of $\mathrm{CFs}$ and organic fertilizers (OFs) will provide a conducive environment for bees to help the pollination process, which will increase the pollination rate, yield, and quality of rockmelon. Therefore, the objective of this study was to observe the effect of the pollination methods (PMs) and integrated fertilizer (IF) on the pollination rate, fruit development, yield, and quality of rockmelon (Cucumis melo L. var. Reticulatus cv. Glamour) under greenhouse conditions.

\section{Materials and Methods}

\subsection{Study Site}

This study was conducted in Field 2, Faculty of Agriculture, Universiti Putra Malaysia (UPM), Serdang, Selangor, Malaysia. This greenhouse was located at $3^{\circ} 0^{\prime} 28.9041^{\prime \prime} \mathrm{N}$ and $101^{\circ} 42^{\prime} 13.1789^{\prime \prime} \mathrm{E}$. Malaysia is a tropical country with a high rainfall rate, namely, $295.0 \mathrm{~mm}$ rainfall from the middle of September to the end of November 2018. The greenhouse was built using a UV plastic film for the roof and 50 mesh white netting to protect the plants from pests, as well as to create a suitable environment in order to control the bees' survival to pollinate rockmelon flowers. The average temperature and relative humidity inside the greenhouse in the morning was $37 \pm 2.67^{\circ} \mathrm{C}$ and $52 \pm 1.74 \%$ and at night was $26 \pm 2.12{ }^{\circ} \mathrm{C}$ and $67 \pm 2.53 \%$, respectively, recorded using a tiny tag TM320 data logger (Dickson Data Loggers, Dickson, Ltd., Addison, IL, USA).

\subsection{Plant Materials and Treatment}

The rockmelon seeds (Cucumis melo L. var. reticulatus cv. Glamour) were obtained from Nine Top Trading Co (M) Sdn. Bhd. located in Rawang, Selangor, Malaysia, and produced by Sakata Seed Corporation, Yokohama, Kanagawa, Japan. The seeds were soaked in water overnight before being placed into the germination tray containing peat moss. After two weeks of germination, or when the seedlings had at least produced three leaves, the rockmelon seedlings were transferred into a $41 \times 41 \mathrm{~cm}$ polybag containing coconut coir dust (CCD) as the growing media. The experiment was arranged in a split plot design and consisted of two factors (integrated fertilizer (IF) and pollination methods $(\mathrm{PMs}))$. The three PMs used as a main plot were arranged in a block under three different greenhouses. Meanwhile, two IFs with four replications (five plants per replication) were arranged randomly in each greenhouse. These two IFs were CFs and OFs; Treatment 1 (T1) $(100 \%$ CF, served as control) and Treatment 2 (T2) $(75 \%$ CF $+25 \%$ OF) as the best integrated fertilizers were obtained from a previous study (unpublished data). The three PMs used in this study were natural pollination (NP), pollination by bees (BP), and human pollination (HP) (Figure 1). The stingless bees (T. thoracica), or lebah kelulut, used in this study were purchased from commercial beekeepers (Figure 2). 

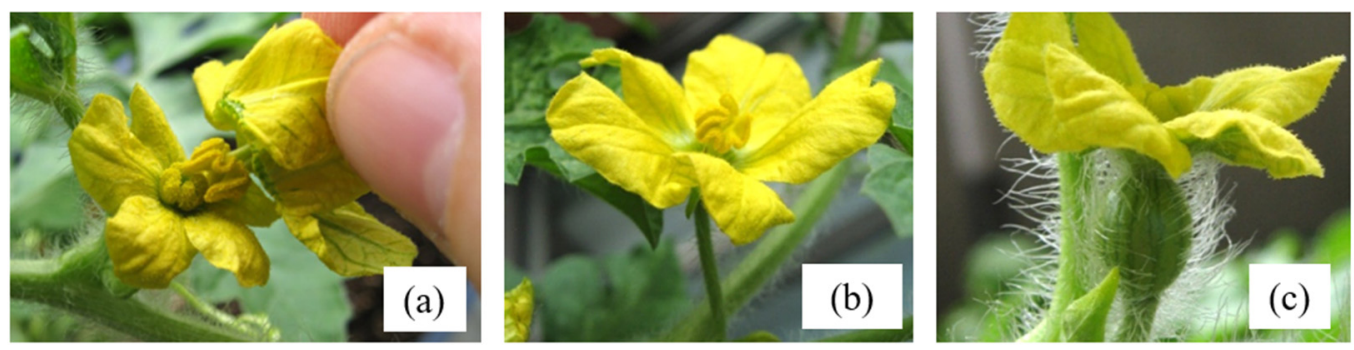

Figure 1. Hand pollination between (a) female and (b) male flowers and successful pollinated flower (c) and developed became fruit.

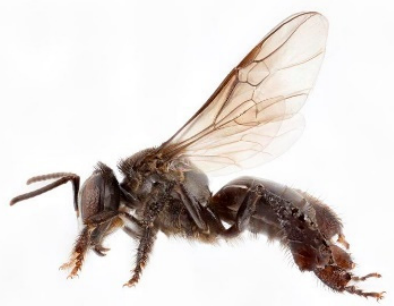

Figure 2. Stingless honey bee (Trigona thoracica) used to pollinate the rockmelon flowers.

\subsection{Watering Method}

Fermentation juice, as an OF resource, and a copper formulation, as the CF, were prepared as described in Supplementary Materials Sections S1 and S2. The fertilizer was applied to the plants using a drip fertigation system according to the treatment (T1 and T2). The fertilizers were prepared and stored separately for the OF and CF solutions. The fertilizers were supplied based on the volume needed by the plant, and the EC rate was controlled following the growth stage of the plants (Table 1).

Table 1. Different volume of integrated fertilizer applied based on the growth stage of rockmelon.

\begin{tabular}{|c|c|c|c|c|c|c|c|c|}
\hline & WAP * & 1-2 & $3-4$ & 5 & 6 & $7-8$ & $9-10$ & 11 \\
\hline \multicolumn{2}{|r|}{ EC Rate } & 0.5 & $1.0-2.0$ & $2.0-2.5$ & 2.5 & 2.5 & 2.5 & 3.0 \\
\hline & & \multicolumn{7}{|c|}{ Volume of fertilizer (mL) } \\
\hline \multirow{2}{*}{$\mathrm{T} 1$} & $100 \% \mathrm{CF}$ & 200 & 400 & 600 & 800 & 1000 & 1000 & 800 \\
\hline & - & - & - & - & - & - & - & - \\
\hline \multirow[b]{2}{*}{$\mathrm{T} 2$} & $75 \% \mathrm{CF}$ & 150 & 300 & 450 & 600 & 750 & 750 & 600 \\
\hline & $25 \% \mathrm{OF}^{* *}$ & 50 & 100 & 150 & 200 & 250 & 250 & 200 \\
\hline
\end{tabular}

Note: * The application of fertilizer was applied following the week after planting (WAP) and the growth stage of the plant is defined as transplanting (1-2 WAP), vegetative growth (3-4 WAP), flowering (5-6 WAP), pollination (7 WAP), fruiting (9 WAP), and harvesting (11-12 WAP). ** Stock solution was prepared by dissolving $5 \mathrm{~L}$ of pure OF in $100 \mathrm{~L}$ of water.

\subsection{Pollination Rate}

The pollination rate is defined as the percentage of success of the fruit set that develop into fruit. Three methods of pollination (PM) - HP, BP, and NP-were carried out under each greenhouse conditions. The PM was carried out when both male and female rockmelon flowers (Figure 1) were ready for the pollination process at the full bloom stage. Only one successful flower turns into fruit from the base, so 10 leaves (flower position between the leaf petioles) were retained for them to grow until the harvesting stage.

For the HP, the male flower was carefully removed from the plants. After this, the petals were stripped away to reveal the stamen, which was carefully inserted into an open female flower and gently tapped on the stigma (the sticky knob) (Figure 1). For the BP, two blocks of stingless bees' nest (1000 bees for each block) were placed inside the greenhouse for a week during the flower bloom stage. For the NP, the plants were left without any pollination agent under greenhouse conditions. 
The success of pollination was determined manually when the flower turned into fruit, which was later expressed as the percentage of successful pollination (fruit set) after the flower had bloomed. Each plant was determined by one flower for fruit to be produced.

The pollination rate for each PM (HP, BP, and NP) was calculated as follows:

$$
\frac{\text { The number of fruit sets in }(\mathrm{HP}+\mathrm{T} 1)+(\mathrm{HP}+\mathrm{T} 2)}{\text { Total Plant }} \times 100 \%
$$

The mean for three pollination rates was calculated as $(\mathrm{HP}+\mathrm{BP}+\mathrm{NP}) / 3$.

The number of dead bees was calculated manually every day when they were found dead on the ground under the greenhouse. The data for dead bees were recorded for seven days after the bees were placed inside the greenhouse.

\subsection{Determination of Yield}

The diameter of rockmelon fruit was measured at one-week intervals from when the flower had bloomed until harvesting. Three selected fruits were randomly marked for each replication and measured using a measuring tape by placing it horizontally around the middle of the fruit. The data were measured continuously using the same fruit until the harvesting stage. The weight of rockmelon fruit was determined during harvesting by using a digital balance scale.

\subsection{Determination of Post-Harvest Quality}

\subsubsection{Firmness and Soluble Solids Concentration}

The firmness of rockmelon fruit was measured using an Instron Universal Testing Machine (Instron Corp., Minneapolis, MN, USA) fitted with a $6 \mathrm{~mm}$ diameter cylindrical probe and a $5 \mathrm{~kg}$ load cell. The Instron probe was inserted into each rockmelon part to a $3 \mathrm{~mm}$ depth at a crosshead speed of $20 \mathrm{~mm} \mathrm{~min}^{-1}$. Each part was inserted three times at equidistance and the data from an instronuniversal testing machine were recorded.

The soluble solids concentration (SSC) of rockmelon juice was determined using a digital refractometer (ATAGO RX-5000, ATAGO CO., LTD, Minato-ku, Tokyo, Japan). Two drops of rockmelon juice were dropped onto the glass prism of the refractometer using a pipet and the reading was recorded. The SSC reading is expressed in percentage (\%) of Brix. The mean of fruit firmness was calculated following the explanation mentioned in Section 2.4.

\subsubsection{Determination of Sugar and Organic Acid Using HPLC}

The internal standard for sugar and organic acid, such as sucrose, D-(+)-glucose, D-(-)-fructose, citric acid, DL-malic acid, and succinic acid, was purchased from Sigma Chemical Corporation (Sigma-Aldrich Chemie GmbH, Steinheim, Germany). Oxalic acid was obtained from Fisher Chemical (Fisher Scientific UK, Loughborough, Leicestershire, UK). While sulfuric acid was obtained from Classic Chemical (Classic Chemicals Sdn. Bhd., Shah Alam, Selangor). All of the chemical standards were of high-performance liquid (HPLC) grade.

The preparation of a standard solution for sugar was obtained by dissolving $0.01 \mathrm{~g}$ of sucrose and fructose in $2 \mathrm{~mL}$ of distilled water, while glucose was prepared by dissolving $0.01 \mathrm{~g}$ in $20 \mathrm{~mL}$ of distilled water. The organic acid was prepared by dissolving $0.1 \mathrm{~g}$ of citric acid, DL-malic acid, oxalic acid, succinic acid, and fumaric acid in $100 \mathrm{~mL}$ of distilled water. Aliquots of standard solutions $(5,10,15,20$, and $25 \mu \mathrm{L})$ were injected into the HPLC system and readings were obtained prior to the development of the regression line.

A total amount of $100 \mathrm{~g}$ of rockmelon fruit was weighed and ground using a multipurpose blender (Panasonic, Panasonic Corporation, Osaka, Japan) for 2 min to obtain fleshy juice of the rockmelon. This fleshy juice was centrifuged for $45 \mathrm{~min}$ at 10,000 rpm and subsequently filtered using filter paper to obtain pure juice [11].

Organic acid and single sugar were determined using the HPLC method [11]. One milliliter of rockmelon juice from each treatment was filtered through $0.22 \mu \mathrm{m}$ PTFE syringe 
filters (Fisher Scientific UK, Loughborough, Leicestershire, UK) before the samples went through HPLC (Agilent 1200 Series, Agilent Technologies Deutschland GmbH, Waldbronn, Germany) coupled to a photodiode array detector (PDA). The analysis was performed using a Shimadzu 20A series HPLC (Shimadzu Corporation, Kyoto, Japan). The HPLC was equipped with an autosampler, column, mobile phase, oven, UV detector, and refractive index (RI) detector. The separation was achieved on a LiChrospher ${ }^{\circledR} 100 \mathrm{NH}_{2}(5 \mu \mathrm{m})$ using a carbohydrate column $(250 \times 4 \mathrm{~mm}$; EMD Serono Inc., Merck KGaA, Darmstadt, Germany) for sugar analysis and a C18 column for organic column $(250 \times 4.60 \mathrm{~mm}$; Phenomenex, Torrence, CA, USA). For organic acid analysis, isocratic elution was carried out with sulfuric acid $(0.05 \mathrm{~m}$; Solvent $\mathrm{A})$ and deionized water (Solvent B) at a ratio of 1:1 and a flow rate of $0.8 \mathrm{~mL} \mathrm{~min}^{-1}$. The detection of organic acid was carried out via photo PDA, using $215 \mathrm{~nm}$ as the preferred wavelength. Sugar analysis involved elution under isocratic conditions with $80 \%$ acetonitrile and $20 \%$ deionized water at a flow rate of $1 \mathrm{~mL} \mathrm{~min}^{-1}$, detected with an RI detector. The results of the organic acid and single sugar were quantified at the peak of the wavelength recorded. The mean of the sugar and organic acid contents was calculated following the explanation mentioned in Section 2.4. The sugar and organic acid content are expressed in milligrams per gram of fresh weight ( $\left.\mathrm{mg} \mathrm{g}^{-1} \mathrm{FW}\right)$.

\subsection{Determination of the Nutrient Content}

Five pieces of fully expanded leaves (numbers 5-10) from the medium surface of the polybag (Figure 3) were sampled during harvesting and dried in an oven at $70{ }^{\circ} \mathrm{C}$ within three to four days. The dried leaves were ground using grinder machines (FFC23, Baker, ESM Machinery (KL) Sdn. Bhd., Balakong, Seri Kembangan, Selangor, Malaysia). The leaf tissue was kept in a dry place at room temperature $\left(24^{\circ} \mathrm{C}\right)$. A total of $0.25 \mathrm{~g}$ of leaf tissue was placed in a digestion flask with $5.0 \mathrm{~mL}$ of $0.05 \mathrm{~m}$ sulfuric acid $\left(\mathrm{H}_{2} \mathrm{SO}_{4}\right)$ and left for $2 \mathrm{~h}$. Then, a total of $2 \mathrm{~mL}$ of $50 \%$ hydrogen peroxide $\left(\mathrm{H}_{2} \mathrm{O}_{2}\right)$ was added to the tube while rotating it. After this, the tube was left in the digestion block for $45 \mathrm{~min}$ for the heating process. Another $2 \mathrm{~mL}$ of $50 \% \mathrm{H}_{2} \mathrm{O}_{2}$ was added again to the tube and left for $45 \mathrm{~min}$, and digestion was allowed until colorless or clear samples were produced, after which the solution was made up to $100 \mathrm{~mL}$ with distilled water. The nutrient content of $\mathrm{N}$ and $\mathrm{P}$ was determined using an auto analyzer (Lachat Instruments, Quick Chem ${ }^{\circledR}$ FIA+ 8000 Series, Milwaukee, WI, USA), while the $\mathrm{K}, \mathrm{Mg}$, and Ca levels were determined using an atomic absorption spectrophotometer (Perkin Elmer Model 310). The mean of the nutrient content was calculated following the explanation mentioned in Section 2.4. The nutrient content is expressed in percentage $(\%)$.

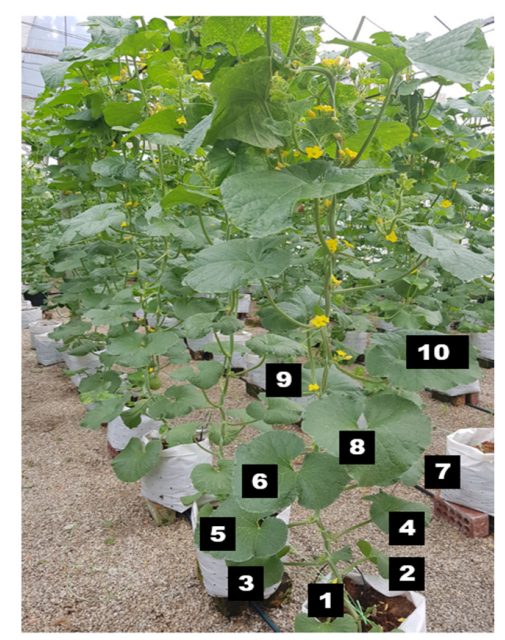

Figure 3. Fully expanded leaves (numbers 5-10) from the medium surface of the polybag were used for nutrient analysis. Numbers 1-10 in the picture indicate the position of the leaves from the medium surface. 


\subsection{Statistical Analysis}

All data were analyzed by analysis of variance (ANOVA) using SAS software (SAS, release 9.3, SAS Institute Inc., Cary, NC, USA). The difference between treatments was compared using Fisher's least significant differences (LSD) test at $p \leq 0.05$. A post-hoc test was carried out to uncover specific differences when an analysis of variance (ANOVA) F-test was significant.

\section{Results and Discussions}

\subsection{Pollination Rate}

Table 2 indicates that the HP and BP were not significantly different from one another, with a $100 \%$ rate of successful pollination; however, both of these pollination methods were significantly different to NP $(0-5 \%)$, which achieved a $95-100 \%$ differentiation of the pollination rate $(p \leq 0.05)$. The pollination rate of NP was found to be the lowest because of the absence of a pollination agent inside the greenhouse system. Additionally, inside the closed greenhouse system, the lack of wind also contributed to the lowest pollination rate among the others (data not recorded). Meanwhile, Table 3 and Figure 1 show the highly significant $(p \leq 0.001)$ interaction values between the PMs (HP, BP, and NP) and IFs (T1 and $\mathrm{T} 2$ ) with $\mathrm{HP}+\mathrm{T} 1, \mathrm{HP}+\mathrm{T} 2$, and $\mathrm{BP}+\mathrm{T} 2$ achieving a 100\% pollination success rate.

Table 2. The main effect on pollination methods (PMs) and integrated fertilizer (IF) on the fertilization rate $(\%)$ of rockmelon.

\begin{tabular}{cc}
\hline Factor & Pollination Rate (\%) \\
\hline Pollination method (PM) & $100.00^{\mathrm{a}}$ \\
HP & $85.00^{\mathrm{a}}$ \\
BP & $2.50^{\mathrm{b}}$ \\
NP & 62.5 \\
\hline Mean & $61.67^{\mathrm{a}}$ \\
\hline Integrated fertilizer (IF) & $68.33^{\mathrm{b}}$ \\
T1 & 65.0 \\
T2 & $0.12^{* * *}$ \\
Mean & $0.23^{* * *}$ \\
$* * *$
\end{tabular}

Table 3. The interaction effect of integrated fertilizers and pollination methods on the pollination rate of rockmelon.

\begin{tabular}{ccc}
\hline Pollination Method & Integrated Fertilizer & Pollination Rate (\%) \\
\hline HP & T1 & $100 \pm 0.00^{\mathrm{a}}$ \\
& T2 & $100 \pm 0.00^{\mathrm{a}}$ \\
\hline BP & T1 & $85 \pm 0^{\mathrm{a}}$ \\
& T2 & $100 \pm 0^{\mathrm{a}}$ \\
\hline NP & T1 & $0 \pm 0^{\mathrm{b}}$ \\
& T2 & $5 \pm 0.28^{\mathrm{b}}$ \\
\hline
\end{tabular}

$\mathrm{a}_{\text {and }}{ }^{\mathrm{b}}$, means with the same letter within a column and factor are not significantly different at $p \leq 0.05$ using LSD. $n=24$. Note: $\mathrm{HP}=$ human pollination; $\mathrm{BP}=$ bee pollination; $\mathrm{NP}=$ natural pollination; $\mathrm{T} 1=100 \% \mathrm{CF} ; \mathrm{T} 2=75 \%$ $\mathrm{CF}+25 \% \mathrm{OF}$. 
There were significant $(p \leq 0.001)$ interaction effects between the PMs and IFs. The HP and BP showed a higher rate, followed by NP. HP and BP provided the highest results due to precise pollination work carried out by a human to ensure successful pollination, or because the bees naturally pollinated rockmelon under greenhouse conditions. The HP and BP showed the same success rate of pollination, so the use of bees in pollinating rockmelon flowers will reduce the need for intensive labor and promote integrated farming at the same time. Another study reported that the fertilization rate is more successfully increased by BP than by HP [3].

Figure 4 shows the interaction effect of IF and PM on the fertilization rate. There was a significant effect $(p \leq 0.05)$ of IF on the rate of fertilization by bees. The application of the T2 fertilizer resulted in a higher rate of fertilization by BP than T1. BP introduced for both IFs showed successful pollination, with T2 being significantly higher than T1 with $6.6 \%$ differentiation. As reported by Power and Stout [12], organic-based products can attract insects to pollinate flowers. This statement was also supported by Banaszak-Cibicka et al. [13], which was that a lower number of bumblebees appeared around field bean plots treated with NPK (inorganic fertilizer) than organic field bean plots. This shows that bees prefer an organic environment over an inorganic one [14]. However, the results of the study show that a mixture of $75 \% \mathrm{CF}$ and $25 \%$ OF (T2) achieved the best result in terms of plant growth (unpublished data). Moreover, Uzman et al. [15] stated that the number of bee species is decreasing due to the abundance of land disturbances as a result of agricultural activities. Additionally, the presence of bees in agricultural activities is affected by the excessive use of CF on commercial farms.

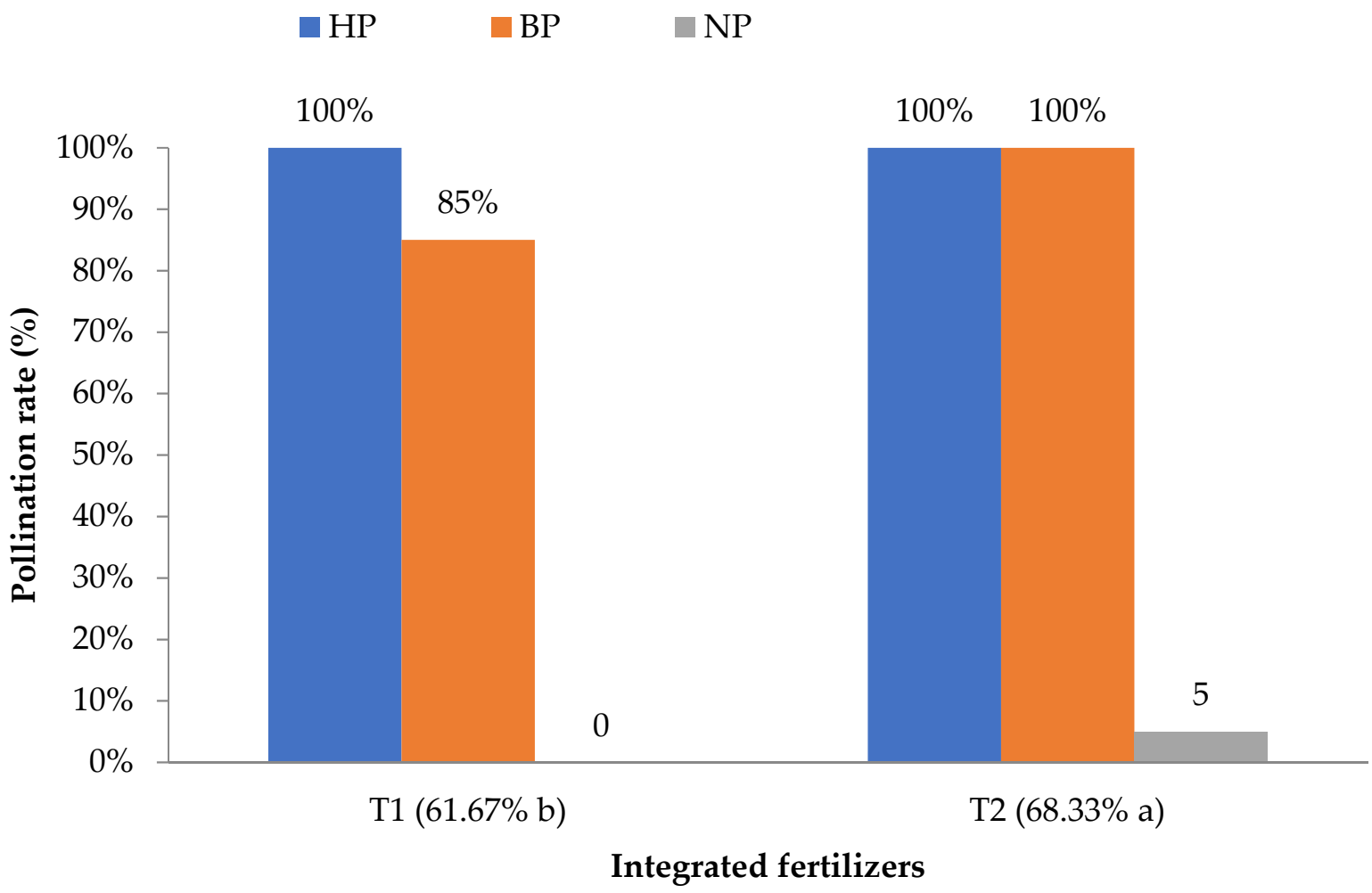

Figure 4. The interaction effect of pollination methods (PM) and integrated fertilizer (IF) on the pollination rate of rockmelon flowers. ${ }^{\mathrm{a}}$ and ${ }^{\mathrm{b}}$, means with the same letter within a column and factor are not significantly different at $p \leq 0.05$ using LSD. $n=24$. Note: $\mathrm{HP}=$ human pollination; $\mathrm{BP}=$ bee pollination; $\mathrm{NP}=$ natural pollination; $\mathrm{T} 1=100 \% \mathrm{CF} ; \mathrm{T} 2=75 \% \mathrm{CF}+25 \% \mathrm{OF}$.

Even though BP helped to increase the pollination rate, we faced challenges in terms of the number of dead bees increasing over time from the moment they were placed inside the greenhouse. Our assumption is well proved in Figure 5: the results showed that the number of dead bees increased more when T2 was placed under greenhouse 
conditions, especially during the hot season from September to November before the rainy season began. The number of dead bees also increased with days after inoculation in the greenhouse conditions (Figure 5). Both of the treatments showed a highly increased number of dead bees until day 3 , thereby decreasing after day 4 . The survival of bees under $\mathrm{T} 1$ was found to decrease, and this was not just because of $\mathrm{CF}$ usage, but also due to the temperature and relative humidity under greenhouse conditions (Figures S1-S6). The highest rate of dead bees at the beginning of placement was because they were unable to adapt to the new environment and the high temperature inside the greenhouse. Li et al. [16] reported that honey bees (Apis cerena and Apis mellifera) can survive up to a temperature of $35^{\circ} \mathrm{C}$, but in our study, the temperature in the greenhouse was higher than that $\left(37^{\circ} \mathrm{C}\right.$ and above) (refer to Figures S1, S3 and S5). Thus, this was determined as a major reason of the death of the bees. Besides this, there was no clear difference between either of the treatments (T1 and T2); the results of the study show that bees placed under greenhouse conditions with the application of CFs encourages a higher number of bee deaths than when the plants are treated with OFs. Therefore, our study indicates that less chemical input in the agriculture sector will protect the environment and produce natural pollinator agents for a sustainable system.

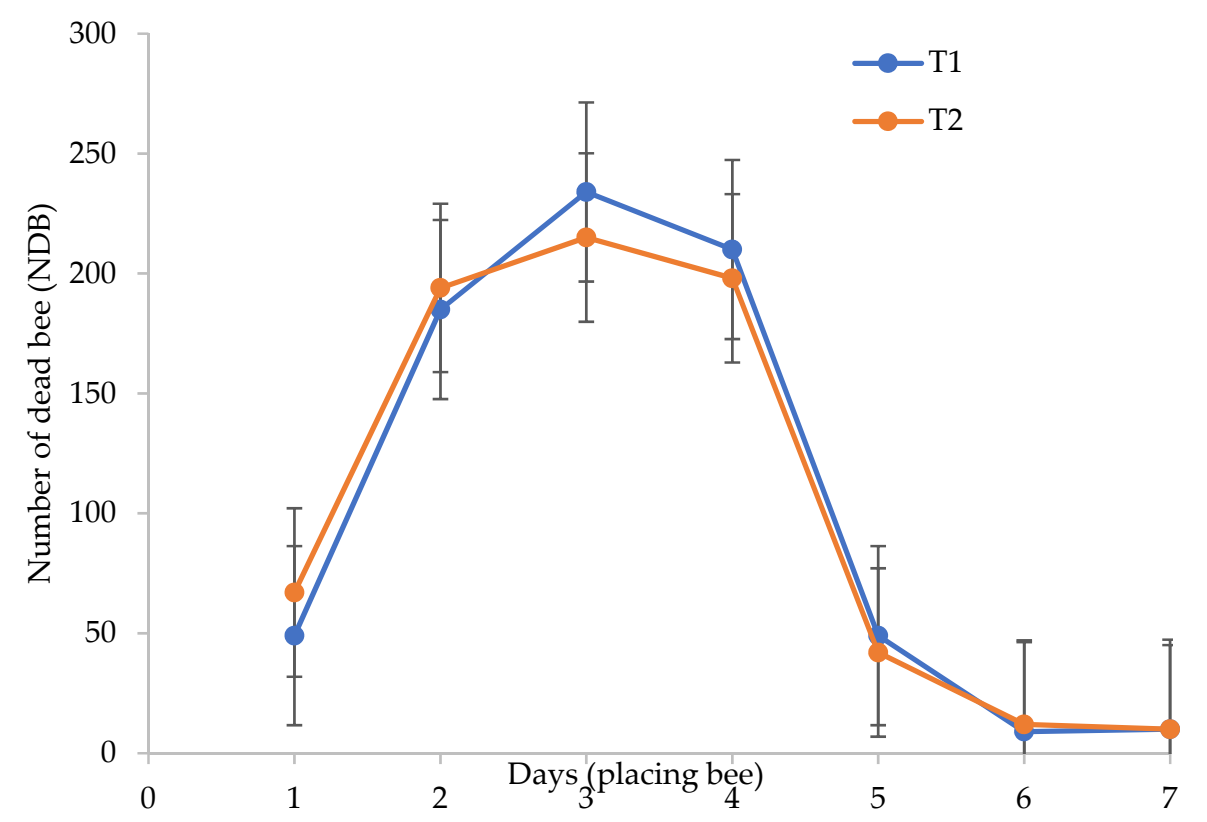

Figure 5. Number of dead bees as influenced by integrated fertilizer (IF) after days of placing. The solid line indicates a significant regression trend at $p \leq 0.05 . n=24$. Note: $\mathrm{T} 1=100 \% \mathrm{CF} ; \mathrm{T} 2=75 \%$ $\mathrm{CF}+25 \%$ OF.

\subsection{Yield}

In this study, the effect of IF and PMs on the diameter of rockmelon fruit during the fruit development stage until harvest was examined. The results showed that the fruit diameter was slightly affected in weeks 1, 3, 4, and 6; however, there were no differences in weeks 2 and 5 . Table 4 shows that in week 6 , the fruit diameter was more dominant for $\mathrm{BP}+\mathrm{T} 1$ (approximately $51 \mathrm{~cm}$ ) and HP $+\mathrm{T} 2$ (approximately $49.25 \mathrm{~cm}$ ). Meanwhile, no significant results were found for $\mathrm{HP}+\mathrm{T} 1$, with $\mathrm{BP}+\mathrm{T} 2$ and $\mathrm{NP}+\mathrm{T} 2$; however, NP + T1 achieved no results at all due to unsuccessful pollination. 
Table 4. The effect of integrated fertilizer and pollination methods on the diameter of rockmelon fruit at every week of fruit development.

\begin{tabular}{|c|c|c|c|c|c|c|c|}
\hline \multirow{2}{*}{\multicolumn{2}{|c|}{ Treatments }} & \multicolumn{6}{|c|}{ Number of Weeks after Flower Bloom (Week) } \\
\hline & & \multirow{2}{*}{$\frac{1}{10.43 \pm 0.36^{b}}$} & \multirow{2}{*}{$\frac{\mathbf{2}}{25.38 \pm 0.28^{\mathrm{a}}}$} & \multirow{2}{*}{$\frac{3}{39.18 \pm 0.09^{b}}$} & \multirow{2}{*}{$\frac{4}{44.88 \pm 0.31^{a}}$} & \multirow{2}{*}{$\frac{5}{46.53 \pm 0.21^{a}}$} & \multirow{2}{*}{$\frac{6}{48.13 \pm 0.12^{b}}$} \\
\hline & $\mathrm{T} 1$ & & & & & & \\
\hline $\mathrm{HP}$ & $\mathrm{T} 2$ & $12.50 \pm 0.06^{\mathrm{a}}$ & $25.83 \pm 0.09^{\mathrm{a}}$ & $40.10 \pm 0.17^{\mathrm{a}}$ & $44.95 \pm 0.15^{\mathrm{a}}$ & $47.10 \pm 0.31^{\mathrm{a}}$ & $49.25 \pm 0.22^{\mathrm{a}}$ \\
\hline \multirow{2}{*}{$\mathrm{BP}$} & $\mathrm{T} 1$ & $12.58 \pm 0.01^{\mathrm{a}}$ & $25.78 \pm 0.11^{\mathrm{a}}$ & $40.50 \pm 0.22^{a}$ & $44.70 \pm 0.27^{\mathrm{a}}$ & $46.83 \pm 0.26^{\mathrm{a}}$ & $51.00 \pm 0.34^{\mathrm{a}}$ \\
\hline & $\mathrm{T} 2$ & $12.65 \pm 0.03^{\mathrm{a}}$ & $25.00 \pm 0.21^{\mathrm{a}}$ & $40.48 \pm 0.04^{\mathrm{a}}$ & $44.85 \pm 0.21^{\mathrm{a}}$ & $47.03 \pm 0.29^{a}$ & $48.63 \pm 0.12^{b}$ \\
\hline \multirow{2}{*}{ NP } & $\mathrm{T} 1$ & $0.00^{\mathrm{c}}$ & $0.00^{\mathrm{c}}$ & $0.00^{\mathrm{c}}$ & $0.00^{\mathrm{c}}$ & $0.00^{\mathrm{c}}$ & $0.00^{\mathrm{c}}$ \\
\hline & $\mathrm{T} 2$ & $12.60 \pm 0.25^{a}$ & $25.50 \pm 0.18^{a}$ & $39.50 \pm 0.27^{b}$ & $43.90 \pm 0.15^{b}$ & $46.40 \pm 0.20^{\mathrm{a}}$ & $48.50 \pm 0.23^{b}$ \\
\hline
\end{tabular}

Values are mean value \pm standard deviation. ${ }^{a},{ }^{b}$ and ${ }^{c}$, means with the same letter within a column and factor indicate no significant difference at $p \leq 0.05$ using LSD. $n=24$. Note: $\mathrm{HP}=$ human pollination; $\mathrm{BP}=$ bee pollination; $\mathrm{NP}=$ natural pollination; $\mathrm{T} 1=100 \% \mathrm{CF}$; $\mathrm{T} 2=75 \% \mathrm{CF}+25 \%$ OF

There was a significant $(p \leq 0.001)$ interaction between PMs and IF on the diameter and fresh weight of rockmelon fruit (Table 5). BP and HP showed higher fruit weight compared to NP. Azmi et al. [17] reported that the rockmelon yield when treated with BP had larger and heavier fruit compared to HP. This result was also supported by Klatt et al. [18], who showed that the yield of strawberries increased and the fruit was much bigger than for NP. Meanwhile, for IF, the application of T2 resulted in a higher fruit diameter than T1. A similar finding was reported by Marzouk and Kaseem [19], in which the fruit weight and diameter increased by the application of NPK integrated with an organic source of fertilizer. In addition, Malik et al. [20] reported a bigger fruit diameter (5.16 and $8.09 \mathrm{~cm}$ ) of the Capsicum hybrid SH-SP-5 treated with NPK $+20 \operatorname{tan~ha}^{-1}$ farmyard manure and $\mathrm{NPK}+40 \tan \mathrm{ha}^{-1}$ farmyard manure, respectively, compared to the control $(4.60 \mathrm{~cm})$. This result was also supported by Lal and Kanaujia [21]: the fruit diameter of acid lime (Citrus aurantifolia) increased compared to the single mineral fertilizer. This study shows that the interaction between IF and PMs had a significant effect on the fruit diameter and weight. Chen et al. [22] reported that OFs enhanced the rate of insect pollinators and the application of fertilizers greatly contributed to a higher number and weight of the berries. Meanwhile, Catarino et al. [23] evidently proved that insect pollinators were outperformed and reduced on land with the excessive use of $\mathrm{CF}$; the yield of oilseed rape also decreased due to the decrease in the number of insect pollinators. Overall, we found that both PM and IF are important for increasing the yield of plants.

Table 5. The main and interaction effects of pollination methods (PM) and integrated fertilizer (IF) on the diameter and fresh weight of rockmelon fruit.

\begin{tabular}{ccc}
\hline Factors & Fruit Diameter $(\mathbf{c m})$ & Fruit Weight $(\mathbf{k g})$ \\
\hline Pollination method (PM) & $36.18^{\mathrm{a}}$ & $1.84^{\mathrm{a}}$ \\
HP & $37.42^{\mathrm{a}}$ & $2.07^{\mathrm{a}}$ \\
BP & $18.20^{\mathrm{b}}$ & $0.95^{\mathrm{b}}$ \\
NP & 30.6 & 1.62 \\
\hline Mean & & $1.36^{\mathrm{b}}$ \\
\hline Integrated fertilizer (IF) & $24.27^{\mathrm{b}}$ & $1.88^{\mathrm{a}}$ \\
T1 & $36.93^{\mathrm{a}}$ & $1.62^{2}$ \\
T2 & 30.6 & $0.22^{* *}$ \\
\hline Mean & $11.23^{* *}$ & $0.17^{* * *}$ \\
\hline LSD of means at $p \leq 0.05$ and levels of significance for a two-factor ANOVA \\
PM & $9.17^{* * *}$ & \\
IF & IF &
\end{tabular}

${ }^{\mathrm{a}}$ and ${ }^{\mathrm{b}}$, means with the same letter within a column and factor are not significantly different at $p \leq 0.05$ using LSD ** Significant at the 0.01 probability level. ${ }^{* * *}$ Significant at the 0.001 probability level. $n=24$. Note: HP $=$ human pollination; $\mathrm{BP}=$ bee pollination; $\mathrm{NP}=$ natural pollination; $\mathrm{T} 1=100 \% \mathrm{CF} ; \mathrm{T} 2=75 \% \mathrm{CF}+25 \% \mathrm{OF}$. 


\subsection{Post-Harvest Quality}

\subsubsection{Firmness and Soluble Solids Concentration}

Table 6 shows the effect of the interaction between PM and IF on the firmness and SSC of rockmelon fruit. There was a significant interaction $(p \leq 0.01)$ between PM and IF on fruit firmness. However, the interaction between both of them did not significantly differ for the SSC of rockmelon fruit. The fruit firmness treated with BP exhibited the highest firmness compared to the other treatments, with no difference between HP and NP. Similar to fruit firmness, the SSC of the BP-treated plants obtained the highest SSC, but with no significant difference compared to NP and HP. Meanwhile, the IF treatment showed significantly higher firmness compared to $\mathrm{CF}$, but there was no difference in the SSC between IF and CF. The mean PM was 9.83, the same as the mean using IF.

Flowers pollinated by BP and fertilized using T2 exhibited the highest $(12.43 \mathrm{~N})$ fruit firmness compared to the other treatments, while the interaction between $\mathrm{BP}+\mathrm{T} 1$ was $34.18 \%$ lower than the BP $+\mathrm{T} 2$ treatment. Klatt et al. [18] claimed that the fruit firmness can be increased by BP. However, the fruit firmness was observed to quickly decrease when treated with $\mathrm{CF}$ due to the fruit achieving the fastest maturity. Fruit that ripens earlier has a lower firmness but a higher SSC and water content [24]. As reported by Partap [25], BP did not only increase the fruit set, but also increased the fruit juices and sugar content in the fruits. A similar finding was found by Abrol et al. [26], who reported that open-pollinated plots (pollination by insects) produce higher-quality compared to the control pollination. The high quality of fruit is not only about size, but also about texture and sweetness [25]. In addition, Garratt et al. [27] reported that Gala apples pollinated by bees have higher firmness $(11.4 \mathrm{~N})$ and sweetness $(11.7 \%)$ than when pollinated by humans. Moreover, all of the results show the bees preferred IF to CF. The rockmelon treated with IF (T2) with BP had higher firmness and sweetness compared to $\mathrm{T} 1$ with the presence of bees as a pollinator. As reported by Pohorecka [28], bees are abundantly found in chemical-free environments compared to agricultural land were CF, herbicides, or pesticides are mainly used. Similarly, Krupke et al. [29] claimed that honey bees living nearest to agricultural fields migrate to new clean environments when chemicals are used excessively in these agricultural fields. Bees are one of the many insects that are naturally beneficial pollinators and contribute more to the success of pollination and enhancing the yield production in agriculture [30].

Table 6. The main and interaction effects of pollination methods (PM) and integrated fertilizer (IF) on the firmness and soluble solids content of rockmelon.

\begin{tabular}{|c|c|c|}
\hline Factors & Fruit Firmness (N) & SSC (Brix) \\
\hline \multicolumn{3}{|c|}{ Pollination method (PM) } \\
\hline $\mathrm{HP}$ & $9.13^{\mathrm{b}}$ & $13.96^{\mathrm{b}}$ \\
\hline $\mathrm{BP}$ & $10.31^{\mathrm{a}}$ & $15.39^{\mathrm{a}}$ \\
\hline NP & $9.04^{\mathrm{b}}$ & $14.09^{\mathrm{ab}}$ \\
\hline Mean & 9.83 & 14.48 \\
\hline \multicolumn{3}{|c|}{ Integrated fertilizer (IF) } \\
\hline $\mathrm{T} 1$ & $7.77^{\mathrm{b}}$ & $14.63^{\mathrm{a}}$ \\
\hline $\mathrm{T} 2$ & $11.22^{\mathrm{a}}$ & $14.33^{\mathrm{a}}$ \\
\hline Mean & 9.83 & 14.48 \\
\hline \multicolumn{3}{|c|}{ LSD of means at $p \leq 0.05$ and levels of significance for a two-factor ANOVA } \\
\hline PM & $0.96^{* * *}$ & $0.81^{* *}$ \\
\hline IF & $0.79^{* * *}$ & $0.67 \mathrm{~ns}$ \\
\hline $\mathrm{PM} \times \mathrm{IF}$ & $* *$ & ns \\
\hline
\end{tabular}




\subsubsection{Sugar and Organic Acid}

Table 7 shows the effect of the interaction between PM and IF on the sugar content of rockmelon. There was no significant interaction between PM and IF in terms of the fructose and glucose content of rockmelon fruit. However, a significant difference in IF was found in all sugar contents of the rockmelon fruit. Moreover, there was a significant interaction $(p \leq 0.001)$ between PM and IF in the sucrose content of rockmelon fruit. Table 7 shows that the BP treatment had the highest sucrose content compared to HP and NP. This is because bees are more attracted to plants fertilized with a combination of CF and OF. In addition, the digestive system of honey bees is perfectly adapted to transform sucrose into fructose and glucose. Evidently, honey bees collect nectar from plants with a high sucrose content than sugar to be transformed into fructose and glucose. A similar result was found in this study, in which rockmelon treated with BP had a higher sucrose content than with the other pollination treatments. Additionally, some other reports have indicated that fruit pollinated with honey bees normally has higher fructose and glucose contents than sucrose content $[25,31,32]$. Fructose and glucose are monosaccharide sugars transformed from sucrose (disaccharide). Plants with a higher sucrose content resulted in a higher sucrose content in rockmelon fruit, making them more attractive for bees to pollinate the flowers. Moreover, honey bees with a higher sucrose than fructose or glucose content have been declared as a plasticity honey bee type [33].

Table 7. The main and interaction effects of pollination methods (PMs) and integrated fertilizer (IF) on the sugar content of rockmelon.

\begin{tabular}{|c|c|c|c|}
\hline \multirow{2}{*}{ Factor } & Fructose & Glucose & Sucrose \\
\hline & \multicolumn{3}{|c|}{$\mathrm{mg} \mathrm{g}^{-1} \mathrm{FW}$} \\
\hline \multicolumn{4}{|c|}{$\begin{array}{l}\text { Pollination method } \\
\qquad(\mathrm{PM})\end{array}$} \\
\hline $\mathrm{HP}$ & $221.33^{a}$ & $255.80^{a}$ & $508.60^{b}$ \\
\hline $\mathrm{BP}$ & $226.58^{\mathrm{a}}$ & $268.81^{a}$ & $597.10^{a}$ \\
\hline NP & $220.26^{a}$ & $258.75^{a}$ & $495.10^{c}$ \\
\hline Mean & 222.72 & 261.12 & 533.60 \\
\hline \multicolumn{4}{|c|}{$\begin{array}{l}\text { Integrated fertilizer } \\
\text { (IF) }\end{array}$} \\
\hline $\mathrm{T} 1$ & $272.95^{\mathrm{a}}$ & $305.74^{\mathrm{a}}$ & $588.70^{a}$ \\
\hline $\mathrm{T} 2$ & $172.96^{\mathrm{b}}$ & $216.51^{b}$ & $478.50^{\mathrm{b}}$ \\
\hline Mean & 222.96 & 261.13 & 533.60 \\
\hline \multicolumn{4}{|c|}{ LSD of means at $p \leq 0.05$ and levels of significance for a two-factor ANOVA } \\
\hline PM & $14.53 \mathrm{~ns}$ & $15.00 \mathrm{~ns}$ & $9.86^{* * *}$ \\
\hline IF & $11.86^{* * *}$ & $12.14^{* * *}$ & $11.78^{* * *}$ \\
\hline $\mathrm{PM} \times \mathrm{IF}$ & ns & ns & $* * *$ \\
\hline
\end{tabular}

$\overline{\mathrm{a}, \mathrm{b}}$ and ${ }^{\mathrm{c}}$, means with the same letter within a column and factor are not significantly different at $p \leq 0.05$ using LSD. ${ }^{* *}$ Significant at the 0.001 probability level. ns, not significant. $n=24$. Note: HP $=$ human pollination; $\mathrm{BP}=$ bee pollination; $\mathrm{NP}=$ natural pollination; $\mathrm{T} 1=100 \% \mathrm{CF} ; \mathrm{T} 2=75 \% \mathrm{CF}+25 \% \mathrm{OF}$.

Figure 6 shows the results of the sugar content for both of IF treatments obtained via HPLC. The results show that sucrose dominated both T1 and T2 compared to fructose and glucose. The sucrose peak was the highest, representing the high sucrose content. Table 7 shows the interaction effect of PM and IF on the sucrose content in rockmelon fruit. Based on the results, plants fertilized with $\mathrm{T} 1$ and BP resulted in a significantly higher $(15.26 \%)$ sucrose content than T2 and the other integration treatments. As discussed earlier, this is due to the application of CF (T1), which resulted in fast maturity and fruit ripening compared to the T2 treatment. Similarly, in our previous study, we showed that T1 resulted in a higher sucrose content than T2-treated plants due to the sufficient nutrient supply to the plants, resulting in a higher sugar content in over-ripened fruit than in moderately ripened 
fruit. However, for market purposes, most fruit suppliers' middlemen and consumers prefer moderately ripened rather than over-ripened fruit because they have a short shelf life compared to mature fruit.

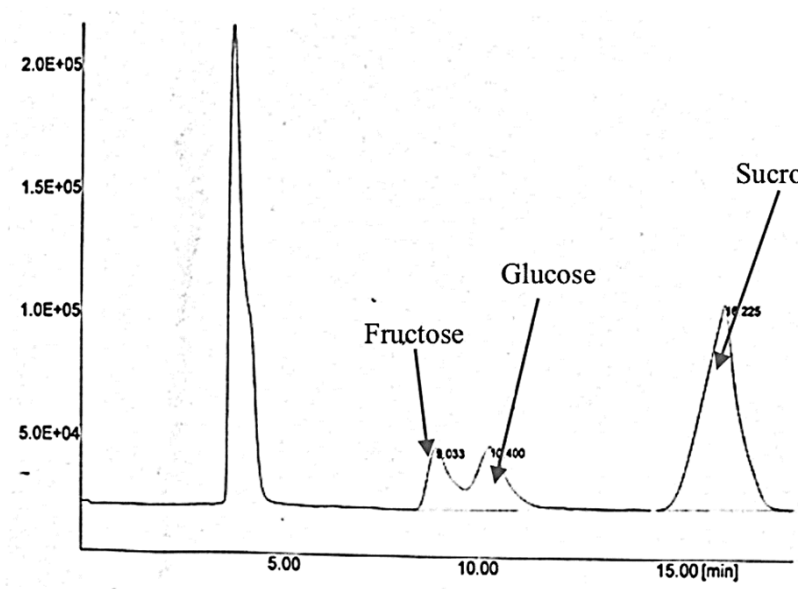

(T1)

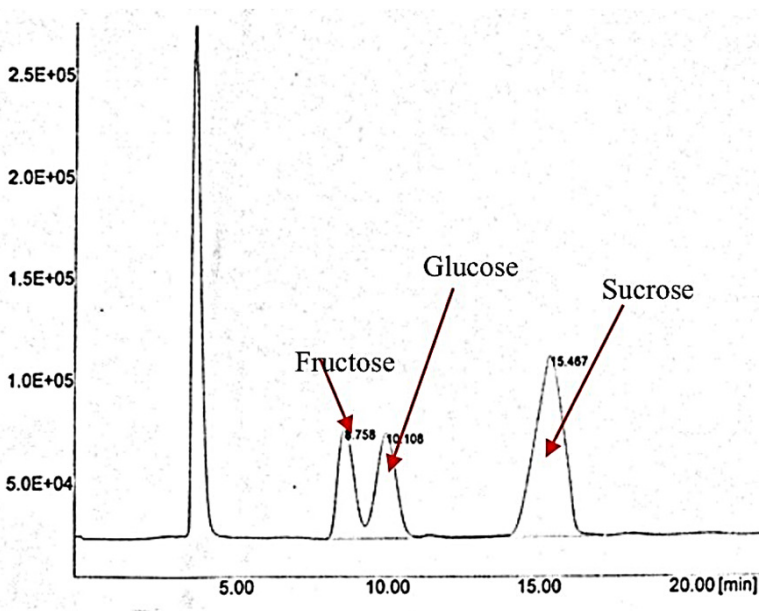

(T2)

Figure 6. A chromatogram of the sugar content of rockmelon juice obtained from HPLC as influenced by IF (T1 and T2).

There was no significant interaction effect between PM and IF in terms of the organic acid contents (oxalic, malic, citric, and succinic) in rockmelon pulp (Table 8). However, the application of IF resulted in a significant difference for all organic acid contents in rockmelon. All of the organic acid contents were higher for T2- than T1-treated plants. Earlier, Kilic at el. [34] reported that the organic acid content is higher in organic compared to inorganic fertilizer treatments. In addition, the T1 treatment resulted in faster fruit ripening than the $\mathrm{T} 2$ treatment, thus resulting in a significantly higher organic acid content in the fruit pulp. As reported by Perkins et al. [35], organic acid decreased during ripening.

Table 8. The main and interaction effects of pollination methods and integrated fertilizer on the organic acid content of rockmelon.

\begin{tabular}{|c|c|c|c|c|}
\hline \multirow{2}{*}{ Factor } & Oxalic & Malic & Citric & Succinic \\
\hline & \multicolumn{4}{|c|}{$\mathrm{mg} \mathrm{g}^{-1} \mathrm{FW}$} \\
\hline \multicolumn{5}{|c|}{$\begin{array}{l}\text { Pollination method } \\
\text { (PM) }\end{array}$} \\
\hline $\mathrm{HP}$ & $0.99^{a}$ & $0.61^{\mathrm{a}}$ & $0.60^{\mathrm{a}}$ & $11.57^{\mathrm{a}}$ \\
\hline $\mathrm{BP}$ & $1.03^{\mathrm{a}}$ & $0.59^{\mathrm{a}}$ & $0.61^{\mathrm{a}}$ & $11.42^{\mathrm{a}}$ \\
\hline NP & $1.04^{\mathrm{a}}$ & $0.60^{\mathrm{a}}$ & $0.60^{\mathrm{a}}$ & $11.61^{\mathrm{a}}$ \\
\hline Mean & 1.02 & 0.60 & 0.60 & 11.53 \\
\hline \multicolumn{5}{|c|}{ Integrated fertilizer (IF) } \\
\hline $\mathrm{T} 1$ & $0.87^{\mathrm{b}}$ & $0.43^{\mathrm{b}}$ & $0.36^{\mathrm{b}}$ & $8.32^{b}$ \\
\hline $\mathrm{T} 2$ & $1.17^{\mathrm{a}}$ & $0.78^{a}$ & $0.85^{\mathrm{a}}$ & $14.74^{\mathrm{a}}$ \\
\hline Mean & 1.02 & 0.60 & 0.60 & 11.53 \\
\hline \multicolumn{5}{|c|}{ LSD of means at $p \leq 0.05$ and levels of significance for a two-factor ANOVA } \\
\hline PM & $0.08 \mathrm{~ns}$ & $0.03 \mathrm{~ns}$ & $0.04 \mathrm{~ns}$ & $0.82 \mathrm{~ns}$ \\
\hline IF & $0.06^{* * *}$ & $0.02 * * *$ & $0.03^{* * *}$ & $0.67^{* * *}$ \\
\hline $\mathrm{PM} \times \mathrm{IF}$ & ns & ns & ns & ns \\
\hline
\end{tabular}

${ }^{\mathrm{a}}$ and ${ }^{\mathrm{b}}$ means with the same letter within a column and factor are not significantly different at $p \leq 0.05$ using LSD *** Significant at the 0.001 probability level. ns, not significant. $n=24$. Note: HP = human pollination; BP = bee pollination; $\mathrm{NP}=$ natural pollination; $\mathrm{T} 1=100 \% \mathrm{CF} ; \mathrm{T} 2=75 \% \mathrm{CF}+25 \% \mathrm{OF}$. 


\subsection{Nutrient Content}

Table 9 shows that there was no significant interaction between PM and IF in terms of the leaf tissue macronutrient content $(\mathrm{N}, \mathrm{P}, \mathrm{K}, \mathrm{Ca}$, and $\mathrm{Mg}$ ) of rockmelon. However, the application of IF had a significant effect on the N, K, Ca, and $\mathrm{Mg}$ contents of the leaf tissue. No significant difference was found in the content of $\mathrm{P}$ in the leaf tissue. The application of $\mathrm{T} 1$ resulted in significantly higher $\mathrm{N}$ and $\mathrm{Mg}$ contents in the leaf tissue, while the application of T2 exhibited significantly higher $\mathrm{K}$ and Ca contents in the leaf tissue. These results are similar to those achieved in our previous study (unpublished data), in which the application of $\mathrm{T} 1$ resulted in higher $\mathrm{N}$ and $\mathrm{Mg}$ contents compared to the use of other IFs, while the application of T2 caused higher $\mathrm{K}$ and Ca contents in the leaf tissue than the other treatments. A similar finding was reported by Ghosh et al. [36], who stated that the application of complete NPK fertilizer and 5 tons ha ${ }^{-1}$ of cow dung resulted in the highest $\mathrm{K}$ uptake (114.26 $\left.\mathrm{kg} \mathrm{ha}^{-1}\right)$ in paddy plants, while single $\mathrm{CF}$ application achieved an uptake of only $108.66 \mathrm{~kg} \mathrm{ha}^{-1}$. However, no significant effect of PM was found on the macronutrient content in the leaf tissue.

Table 9. The main and interaction effects of pollination methods (PM) and integrated fertilizer (IF) on the leaf tissue macronutrient content of rockmelon.

\begin{tabular}{|c|c|c|c|c|c|}
\hline \multirow{2}{*}{ Factor } & $\mathbf{N}$ & $\mathbf{P}$ & $\mathbf{K}$ & $\mathrm{Ca}$ & Mg \\
\hline & \multicolumn{5}{|c|}{$\%$} \\
\hline \multicolumn{6}{|c|}{$\begin{array}{l}\text { Pollination method } \\
\text { (PM) }\end{array}$} \\
\hline $\mathrm{HP}$ & $32.79^{a}$ & $11.83^{\mathrm{a}}$ & $23.35^{\mathrm{a}}$ & $25.54^{\mathrm{a}}$ & $4.39^{\mathrm{a}}$ \\
\hline $\mathrm{BP}$ & $32.56^{\mathrm{a}}$ & $11.51^{\mathrm{a}}$ & $23.50^{a}$ & $25.34^{a}$ & $4.38^{\mathrm{a}}$ \\
\hline NP & $33.05^{\mathrm{a}}$ & $11.38^{a}$ & $23.38^{\mathrm{a}}$ & $25.33^{a}$ & $4.13^{\mathrm{a}}$ \\
\hline Mean & 32.80 & 11.57 & 23.41 & 25.40 & 4.30 \\
\hline \multicolumn{6}{|c|}{$\begin{array}{l}\text { Integrated fertilizer } \\
\text { (IF) }\end{array}$} \\
\hline $\mathrm{T} 1$ & $36.99^{a}$ & $11.48^{\mathrm{a}}$ & $22.30^{b}$ & $24.01^{b}$ & $4.94^{\mathrm{a}}$ \\
\hline $\mathrm{T} 2$ & $28.61^{b}$ & $11.66^{\mathrm{a}}$ & $24.52^{\mathrm{a}}$ & $26.79^{a}$ & $3.66^{b}$ \\
\hline Mean & 32.80 & 11.57 & 23.41 & 25.40 & 4.30 \\
\hline \multicolumn{6}{|c|}{ LSD of means at $p \leq 0.05$ and levels of significance for a two-factor ANOVA } \\
\hline PM & $1.39 \mathrm{~ns}$ & $0.86 \mathrm{~ns}$ & $0.49 \mathrm{~ns}$ & $1.07 \mathrm{~ns}$ & $0.41 \mathrm{~ns}$ \\
\hline IF & $1.14^{* * *}$ & $0.70 \mathrm{~ns}$ & $0.40 * * *$ & $0.87^{* * *}$ & $0.33^{* * *}$ \\
\hline $\mathrm{PM} \times \mathrm{IF}$ & ns & ns & ns & ns & ns \\
\hline
\end{tabular}

${ }_{\mathrm{a}}$ and $^{\mathrm{b}}$ means with the same letter within a column and factor are not significantly different at $p \leq 0.05$ using LSD ${ }^{* * *}$ Significant at the 0.001 probability level. ns, not significant. $n=24$. Note: HP = human pollination; BP = bee pollination; $\mathrm{NP}=$ natural pollination; $\mathrm{T} 1=100 \% \mathrm{CF} ; \mathrm{T} 2=75 \% \mathrm{CF}+25 \% \mathrm{OF}$.

\section{Conclusions}

Pollination by bees (BP) or insects is common for open planting, especially in fields. In a closed planting system, humans act as pollution agents in order to increase the successful rate of fertilization. Introducing bees under greenhouse conditions resulted in a successful fertilization rate, and the bees were always ready to pollinate whenever the flowers started to "bloom". It is recommended that growers use bees as pollination agents, which can also help farmers to reduce the cost and time of labor, besides introducing integrated farming between plants and insects (bee). This study proved that introducing BP inside greenhouses can increase the fertilization rate in comparison to HP. Additionally, the fruit quality was also found to have improved following BP compared to HP and NP. However, the death rate of bees increased over time after placing the bees in the greenhouse due to the hot temperature under tropical climate conditions. Therefore, further study is needed to determine the most suitable environmental conditions in the greenhouse to suit the natural requirements of bees, such as controlling the temperature and relative 
humidity. By providing a suitable environment for bees, we hope that the survival rate of bees as pollinator agents will increase and boost the production of rockmelon in a greenhouse system.

The integrated fertilizer T2 $(75 \% \mathrm{CF}+25 \%$ OF) resulted in the highest yield and post-harvest quality. The outcome of this study provides a positive view of the potentially integrated fertilizer that combines OF and CF. Through this method, the OF consumption can be increased, and at the same time, the environment can be protected and the production costs can be reduced. Our study proved that the nutrient availability in CF was quickly and readily taken up by the plant, where, at the end of the planting period, it contributed to a higher yield. However, single OF can cause an imbalance in growth and a low yield due to deficiency of the nutrient, resulting in the greatest loss for farmers. In conclusion, the integrated fertilizer T2 was determined to be able to increase the yield and quality of rockmelon (var. Glamour) and reduce the amount of $\mathrm{CF}$ by adding OF, thus creating a sustainable food production system.

Supplementary Materials: The following are available online at https:/ /www.mdpi.com/article/10 $.3390 /$ su132313300/s1, Table S1: Preparation of copper formulation in $30 \mathrm{~L}$ of stock fertilizer, Table S2: The nutrient content in BFJ, Figure S1: The temperature inside the greenhouse of hand pollination (HP) method during experimental period at $10.00 \mathrm{am}$, Figure S2: The relative humidity inside the greenhouse of hand pollination (HP) method during experimental period at $10.00 \mathrm{am}$, Figure S3: The temperature inside the greenhouse of bee pollination (BP) method during experimental period at $10.00 \mathrm{am}$, Figure S4: The relative humidity inside the greenhouse of bee pollination (BP) method during experimental period at $10.00 \mathrm{am}$, Figure S5: The temperature inside the greenhouse of natural pollination (NP) method during experimental period at $10.00 \mathrm{am}$, Figure S6: The relative humidity inside the greenhouse of natural pollination (NP) method during experimental period at $10.00 \mathrm{am}$, Figure S7: The chromatogram of organic acid content of rockmelon juice obtained from HPLC as influenced by HP treatment, Figure S8: The chromatogram of organic acid content of rockmelon juice obtained from HPLC as influenced by BP treatment, Figure S9: The chromatogram of organic acid content of rockmelon juice obtained from HPLC as influenced by NP treatment.

Author Contributions: Conceptualization, N.Z.N.H. and S.Z.S.; methodology, N.Z.N.H. and S.Z.S.; software, N.Z.N.H.; validation, N.Z.N.H. and S.Z.S.; formal analysis, N.Z.N.H.; investigation, N.Z.N.H. and S.Z.S.; resources, S.Z.S.; data curation, N.Z.N.H.; writing-original draft preparation, N.Z.N.H.; writing-review and editing, S.Z.S.; visualization, S.Z.S.; supervision, S.Z.S. and N.M.J.; project administration, S.Z.S. and N.Z.N.H.; funding acquisition, I.Z.I. All authors have read and agreed to the published version of the manuscript.

Funding: This research was funded by the Ministry of Agriculture (MOA), grant number 21003001500001, titled "Improvement of Organic Green Farming Practices and Ecosystem Conservation".

Institutional Review Board Statement: Not applicable.

Informed Consent Statement: Not applicable.

Data Availability Statement: Not applicable.

Acknowledgments: The authors would like to express their gratitude to the Malaysian Agriculture Research and Development Institute (MARDI) for providing financial grant support to conduct the research at the Faculty of Agriculture, Universiti Putra Malaysia. The main author also would like to thank all faculty members and staff of the Department of Crop Science for their continuous technical support and cooperation to complete the research.

Conflicts of Interest: The authors declare no conflict of interest.

\section{References}

1. Sengupta, P.; Ghorai, N.; Bera, S. On the Quantification of Information Content of Flower-Insect Interaction by the Species Diversity Indices: A Case Study in Flower Visiting Hymenopterans. In Proceedings of the Zoological Society; Springer: Berlin, Germany, 2012; Volume 65, pp. 57-60.

2. Robinson, W.S. Migrating Giant Honey Bees (Apis Dorsata) Congregate Annually at Stopover Site in Thailand. PLoS ONE 2012, 7, e44976. [CrossRef] [PubMed] 
3. Nicholls, C.I.; Altieri, M.A. Plant biodiversity enhances bees and other insect pollinators in agroecosystems. A review. Agron. Sustain. Dev. 2013, 33, 257-274. [CrossRef]

4. Jusoh, M.F.; Adnan, N.; Abdul Muttalib, M.F.; Katimon, A. Performance Evaluation of Drip Irrigation System and Water Productivity (WP) of Rock Melon Grown inside Netted Rain House Shelter. IOP Conf. Ser. Earth Environ. Sci. 2020, $549,012094$. [CrossRef]

5. Bennett, B.C. Twenty-Five Economically Important Plant Families. Available online: https://www.eolss.net/Sample-Chapters/ C09/E6-118-03.pdf (accessed on 8 September 2020).

6. Belavadi, V.V. Floral biology and pollination in Cucumis melo L., a tropical andromonoecious cucurbit. J. Asia-Pac. Entomol. 2019, $22,215-225$.

7. Naik, S.; Rana, V. Spray pollination: An efficient and labour saving method for kiwifruit (Actinidia deliciosa A. Chev.) production. J. Appl. Hortic. 2013, 15, 202-206. [CrossRef]

8. Hall, M.A.; Jones, J.; Rocchetti, M.; Wright, D.; Rader, R. Bee visitation and fruit quality in berries under protected cropping vary along the length of polytunnels. J. Econ. Entomol. 2020, 113, 1337-1346. [CrossRef]

9. Jung, C.; Cho, S.K. Relationship between honeybee population and honey production in Korea: A historical trend analysis. J. Apic. 2015, 30, 7-12. [CrossRef]

10. Porrini, C.; Caprio, E.; Tesoriero, D.; Di Prisco, G. Using honey bee as bioindicator of chemicals in Campanian agroecosystems (South Italy). Bull. Insectol. 2014, 67, 137-146.

11. Pereira, C.; Barros, L.; Carvalho, A.M.; Ferreira, I.C. Use of UFLC-PDA for the analysis of organic acids in thirty-five species of food and medicinal plants. Food Anal. Methods 2013, 6, 1337-1344. [CrossRef]

12. Power, E.F.; Stout, J.C. Organic dairy farming: Impacts on insect-flower interaction networks and pollination. J. Appl. Ecol. 2011, 48, 561-569. [CrossRef]

13. Banaszak-Cibicka, W.; Takacs, V.; Kesy, M.; Langowska, A.; Blecharczyk, A.; Sawinska, Z.; Tryjanowski, P. Manure application improves both bumblebee flower visitation and crop yield in intensive farmland. Basic Appl. Ecol. 2019, 36, 26-33. [CrossRef]

14. Negri, I.; Mavris, C.; Di Prisco, G.; Caprio, E.; Pellecchia, M. Honey bees (Apis mellifera L.) as active samplers of airborne particulate matter. PLOS ONE 2015, 10, e0132491. [CrossRef] [PubMed]

15. Uzman, D.; Reineke, A.; Entling, M.H.; Leyer, I. Habitat area and connectivity support cavity-nesting bees in vineyards more than organic management. Biol. Conserv. 2020, 242, 108419. [CrossRef]

16. Li, X.; Ma, W.; Shen, J.; Long, D.; Feng, Y.; Su, W.; Jiang, Y. Tolerance and response of two honeybee species Apis cerana and Apis mellifera to high temperature and relative humidity. PLoS ONE 2019, 14, e0217921. [CrossRef]

17. Azmi, W.A.; Wan Sembok, W.Z.; Yusuf, N.; Mohd Hatta, M.F.; Salleh, A.F.; Hamzah MA, H.; Ramli, S.N. Effects of Pollination by the Indo-Malaya Stingless Bee (Hymenoptera: Apidae) on the Quality of Greenhouse-Produced Rockmelon. J. Econ. Entomol. 2019, 112, 20-24. [CrossRef]

18. Klatt, B.K.; Holzschuh, A.; Westphal, C.; Clough, Y.; Smit, I.; Pawelzik, E.; Tscharntke, T. Bee pollination improves crop quality, shelf life and commercial value. Proc. R. Soc. B 2014, 281, 20132440. [CrossRef]

19. Marzouk, H.A.; Kassem, H.A. Improving fruit quality, nutritional value and yield of Zaghloul dates by the application of organic and/or mineral fertilizers. Sci. Hortic. 2011, 127, 249-254. [CrossRef]

20. Malik, A.A.; Chattoo, M.A.; Sheemar, G.; Rashid, R. Growth, yield and fruit quality of sweet pepper hybrid SH-SP-5 (Capsicum annuи L.) as affected by integration of inorganic fertilizers and organic manures (FYM). J. Agric. Technol. 2011, 7, $1037-1048$.

21. Lal, G.; Dayal, H. Effect of integrated nutrient management on yield and quality of acid lime (Citrus aurantifolia Swingle). Afr. J. Agric. Res. 2014, 9, 2985-2991.

22. Chen, K.; Fijen, T.P.; Kleijn, D.; Scheper, J. Insect pollination and soil organic matter improve raspberry production independently of the effects of fertilizers. Agric. Ecosyst. Environ. 2021, 309, 107270. [CrossRef]

23. Catarino, R.; Bretagnolle, V.; Perrot, T.; Vialloux, F.; Gaba, S. Bee pollination outperforms pesticides for oilseed crop production and profitability. Proc. R. Soc. B 2019, 286, 20191550. [CrossRef]

24. Ghai, K.; Gupta, P.K.; Gupta, A.K. Physiochemical behavior changes during ripening in fruits of Trewia nudiflora Linn. Perspect. Sci. 2016, 8, 596-598. [CrossRef]

25. Partap, U.; Partap, T. Pollination of apples in China. Beekeep. Dev. 2000, 54, 6-7.

26. Abrol, D.P.; Gorka, A.K.; Ansari, M.J.; Al-Ghamdi, A.; Al-Kahtani, S. Impact of insect pollinators on yield and fruit quality of strawberry. Saudi J. Biol. Sci. 2019, 26, 524-530. [CrossRef] [PubMed]

27. Garratt, M.P.; Breeze, T.D.; Jenner, N.; Polce, C.; Biesmeijer, J.C.; Potts, S.G. Avoiding a bad apple: Insect pollination enhances fruit quality and economic value. Agric. Ecosyst. Environ. 2014, 184, 34-40. [CrossRef] [PubMed]

28. Pohorecka, K.; Szczęsna, T.; Witek, M.; Miszczak, A.; Sikorski, P. The exposure of honey bees to pesticide residues in the hive environment with regard to winter colony losses. J. Apic. Sci. 2017, 61, 105. [CrossRef]

29. Krupke, C.H.; Hunt, G.J.; Eitzer, B.D.; Andino, G.; Given, K. Multiple routes of pesticide exposure for honey bees living near agricultural fields. PLoS ONE 2012, 7, e29268. [CrossRef]

30. Garibaldi, L.A.; Carvalheiro, L.G.; Leonhardt, S.D.; Aizen, M.A.; Blaauw, B.R.; Isaacs, R.; Winfree, R. From research to action: Enhancing crop yield through wild pollinators. Front. Ecol. Environ. 2014, 12, 439-447. [CrossRef]

31. Kamal, M.A.; Klein, P. Determination of sugars in honey by liquid chromatography. Saudi J. Biol. Sci. 2011, 18, 17-21. [CrossRef] 
32. Buba, F.; Gidado, A.; Shugaba, A. Analysis of biochemical composition of honey samples from North-East Nigeria. Biochem. Anal. Biochem. 2013, 2, 139 .

33. Wheeler, M.M.; Robinson, G.E. Diet-dependent gene expression in honey bees: Honey vs. sucrose or high fructose corn syrup. Sci. Rep. 2014, 4, 5726. [CrossRef] [PubMed]

34. Kilic, N.; Burgut, A.; Gündesli, M.A.; Nogay, G.; Ercisli, S.; Kafkas, N.E.; Szopa, A. The Effect of Organic, Inorganic Fertilizers and Their Combinations on Fruit Quality Parameters in Strawberry. Horticulturae 2021, 7, 354. [CrossRef]

35. Perkins, D.M.; Mckie, B.G.; Malmqvist, B.; Gilmour, S.G.; Reiss, J.; Woodward, G. Environmental warming and biodiversityecosystem functioning in freshwater microcosms: Partitioning the effects of species identity, richness and metabolism. Adv. Ecol. Res. 2010, 43, 177-209.

36. Ghosh, K.; Chowdhury MA, H.; Rahman, M.H.; Bhattacherjee, S. Effect of integrated nutrient management on nutrient uptake and economics of fertilizer use in rice cv. Nerica 10. J. Bangladesh Agric. Univ. 2014, 12, 273-277. [CrossRef] 